A N N A L E S

UNIVERSITATIS M A R A E C URIE-SKŁODOW S A

LUBLIN - POLONIA

VOL. XXXII, 4

SECTIO J

2019

Uniwersytet Rzeszowski. Wydział Pedagogiczny

WALDEMAR FURMANEK

ORCID: 0000-0002-1032-4266

furmanek@ur.edu.pl

\title{
Zagubione obszary polskiej pedagogiki. Część 2
}

Lost Areas of Polish Pedagogy. Part 2

\section{STRESZCZENIE}

W niniejszym opracowaniu przedstawiono katalogi problemów zestawiające najważniejsze z zagubionych obszarów polskiej pedagogiki. Uwagę zwrócono na konieczność jasnego określenia misji nauk pedagogicznych. Nie może ona pomijać odpowiedzi na pytanie o istotę człowieka (problemy antropologii i aksjologii). Te zaś nawiązują do filozoficznych podstaw współczesnej pedagogiki. Przyjęty obraz człowieka wskazuje na atrybuty podmiotu: człowieka jako osoby (uzupełnienie paradygmatu naturalistycznego paradygmatem humanistycznym). W odniesieniu do tych atrybutów człowieka odnosi się działalność pedagogiczną. Jej istotą jest wspomaganie procesów rozwojowych. Nie mniej ważne jest to wszystko, co wiąże się z tzw. dziedzinami wychowania (edukacji). Istnieje konieczność rezygnacji z upowszechnionego w tym zakresie addytywizmu. Jak należy postrzegać tę problematykę w świetle wymagań metodologii badań systemowych i wyzwań współczesnej cywilizacji wiedzy? Wszystko to znajduje odzwierciedlenie w zagubionej problematyce aksjologii pedagogicznej oraz problematyce wychowania w świetle i ku wartościom. Problematyka uczenia się człowieka - w kontekście wszechobecnych technologii informacyjnych - także wymaga nowego ujęcia, a to reorganizuje problematykę dydaktyk szczegółowych, w tym edukacji zawodowej.

Słowa kluczowe: antropologia; wychowanie; zaniedbania; zagubienie; teoria wychowania; teoria nauczania

\section{WPROWADZENIE}

Co jest szczególnym przedmiotem badań pedagogicznych? Skoro pedagogika jest systemem dyscyplin naukowych, to ma wspólny dla wielu jej dyscyplin 
obiekt dociekań naukowych. Jest nim człowiek, wędrująca i pulsująca kategoria naukowa. To jak interpretujemy tę kategorię, ukierunkowuje nasze dalsze myślenie i siatkę pojęciową. Przyjęty model człowieka stanowi o swoistości przedmiotu wszelkich badań pedagogicznych.

Czy pedagogika jest nauką humanistyczną? Przedmiotem zainteresowań wszystkich dyscyplin humanistycznych (w tym pedagogicznych) jest człowiek. Konsekwencje tego stanowiska są wielorakie. Pierwszą z nich jest odmienne widzenie człowieka i uznanie tego, że niezaprzeczalnymi atrybutami osoby ludzkiej są: godność jako poczucie własnej wartości, samoświadomość wartości, jedyność (zwana też indywidualizmem lub jednorazowością), przeżywanie świata i swojego w nim istnienia (zwłaszcza w odniesieniu do wartości, egzystowania) oraz otwartość podczas nieustającego procesu stawania się człowiekiem (dziejowość, zmienność w czasie, transgresja).

Zauważmy tylko dla ilustracji tej kwestii, że przyjmowanie założeń naturalizmu, a więc paradygmatu naturalistycznego (scjentystycznego), w przyrodniczym oglądzie człowieka jako obiektu badań rzutuje na dalszą wizję pedagogiki. Przyjęcie paradygmatu humanistycznego, antynaturalistycznego (choćby jako dopełniającego obraz człowieka), zmienia optykę postrzegania całej problematyki badań.

Dalej w działalności pedagogicznej opracowuje się naukowo pozytywny sposób oddziaływania na tak rozumianego człowieka w celu osiągnięcia pożądanych zmian. Owe zmiany rozwojowe, stanowiące także wyniki działalności pedagogicznej, są również rozmaicie postrzegane (np. w pedagogice humanistycznej jako rozwinięcie człowieczeństwa jednostki ludzkiej). To oddziaływanie (a w istocie - taka działalność) wynika z faktu bezwzględnie koniecznej potrzeby wspomagania człowieka w jego życiu i rozwoju, w procesie stawania się człowiekiem. Wspomaganie jest procesem świadomego działania człowieka, ukierunkowanego na dobro człowieka. Stanowi najbardziej wyrazistą i charakterystyczną misję wszelkich dyscyplin pedagogicznych. Może mieć charakter działań: a) kreatywnych (gdy zamierza np. wywołać, ukształtować), b) optymalizujących (gdy zamierza np. wzmóc, zwiększyć), c) minimalizujących (gdy zamierza np. osłabić, ograniczyć), d) korekcyjnych (gdy zamierza np. przekształcić, zmienić).

Pytanie o to, dlaczego istnieje taka bezwzględna konieczność wspomagania procesów rozwojowych człowieka, wynika z natury faktów związanych z każdym przyjściem człowieka na świat. Człowiek bowiem rodzi się - w każdym wymiarze swojego bytu - nieprzystosowany do życia w nowych, jakże odmiennych od łona matki warunkach. Aby przeżył i rozwijał się, konieczna jest wieloraka i zróżnicowana działalność dorosłych. Jej zakres, treść, sprawność i skuteczność zależy od wielu różnorodnych czynników. Niemniej jest to działalność konieczna. Gdyby człowiek przychodził na świat jako byt skończony, czyli w pełni rozwinięty, nie wymagałby owego wspomagania. Wtedy także nie byłaby potrzebna pedagogika z jej rozmaitością dyscyplin naukowych. 
Jeżeli nauki o wychowaniu (działalności wychowawczej) chcą podejmować badania w tym zakresie, to muszą być ukierunkowane na studiowanie tego specyficznego zjawiska ludzkiego obecnego w historii naszej cywilizacji, a konkretnie mówiąc - na badanie relacji wychowawczych jako zdarzeń zachodzących w konkretnym miejscu i czasie, między konkretnymi jednostkami, według pewnej strategii działania. Takie stanowisko prezentowali w Polsce liczni pedagodzy. Wymieńmy tylko przykładowo Antoninę Gurycką (1989), Teresę Kukołowicz (1995), Teresę Hejnicką-Bezwińską (1995), Mariana Nowaka (2009).

\section{OBSZARY ZAGUBIENIA WSPÓŁCZESNEJ PEDAGOGIKI}

System zagubionych problemów współczesnej pedagogiki według Stanisława Palki (2010) obejmuje takie obszary, jak:

- charakterystyka pedagogiki jako nauki,

- nauki pomocnicze pedagogiki,

- ontologiczne, epistemologiczne, antropologiczne podstawy pedagogiki,

- język naukowy pedagogiki,

- istota i rola wychowania (kształcenia),

- filozoficzne, psychologiczne, kulturowe i socjologiczne uwarunkowania pedagogiki,

- kulturowe i biologiczne podstawy wychowania,

- teleologia i aksjologia wychowania (kształcenia),

- prawidłowości wychowania i kształcenia,

- teoretyczne systemy wychowania,

- cele, treści, zasady, metody, formy i środki działalności pedagogicznej,

- krytyczna analiza teoretycznych stanowisk, prądów, doktryn i kierunków pedagogicznych,

- metodologia pedagogiki (ogólna i szczegółowa metodologia badań pedagogicznych).

Nic dodać, nic ująć. Katalog problematyki współczesnej polskiej pedagogiki wymagającej pilnych badań w ujęciu Palki jest wielce wymowny. Zauważmy, że obejmuje on to, co w podręcznikach do pedagogiki przeznaczonych dla studiujących ten kierunek studiów stanowi kanon treści ujmowanych w poszczególnych sylabusach przedmiotów ujętych w planach studiów.

Zwrócę uwagę na dwie kwestie: język pedagogiki oraz uczenie się. Odnośnie do języka naukowego pedagogiki należy zauważyć, że istnieje pilna potrzeba reinterpretacji niemal wszystkich podstawowych kategorii naukowych pedagogiki. Dziś już nie wystarczają interpretacje zawarte w znanych słownikach i leksykonach pedagogiki (por. Śliwerski, 2015). Brak jednoznaczności terminologicznej utrudnia, a nawet uniemożliwia nie tylko transkomunikatywność (przekładalność wyników na język teorii pokrewnych), lecz także 
formułowanie tzw. reguł prakseologicznych. Nie sprzyja to rozwojowi badań pedagogicznych.

W zakresie uczenia się człowieka - w świetle nowych teorii dotyczących zarówno istoty człowieka, jak i praw uczenia się - istnieje konieczność pogłębionych badań, jakże fundamentalnych dla wszystkich dydaktyk szczegółowych. A jak należy postrzegać uczenie się w kontekście technologii informacyjnych?

I. Zagubienia w pedagogice ogólnej:

1. Filozofia człowieka, filozofia wychowania, filozofia edukacji.

2. Filozoficzne i antropologiczne podstawy współczesnej pedagogiki.

3. Aksjologia pedagogiczna, w tym zagubienie prawdy. Dyktatura relatywizmu.

II. Obszary zaniedbane polskiej pedagogiki:

1. System kształcenia, dokształcania i doskonalenia nauczycieli.

2. Wykorzystanie IT w systemie oświaty. Trudno w to uwierzyć, ale badania sondażowe pokazują, że poziom alfabetyzacji informatycznej nauczycieli jest żenująco niski. Poza tym można wskazać znaczące grupy nauczycieli zaliczanych do analfabetów funkcjonalnych.

3. Wychowanie w zakresie kultury informatycznej, cyberbezpieczeństwo.

4. Kształcenie techniczne. Rozwijanie kultury technicznej. Racjonalne wykorzystanie technologii informatycznych i informacyjnych.

5. Indoktrynacja w systemach oświatowych (zakłamania).

6. Rozwiązywanie konfliktogennych procesów oświatowych. Ważne zwłaszcza w kontekście toczących się debat - są argumenty w dyskusji na temat strategii zarządzania oświatą, reformy oświaty, podstawy programowej kształcenia ogólnego, kanonu lektur szkolnych, edukacji seksualnej, dyscypliny w szkole, szans edukacyjnych i płci dzieci w szkole.

III. Zagubienia w teorii i praktyce wychowania:

1. Niejednoznaczność co do istoty zjawisk wychowania.

2. Wychowanie aksjologiczne jako idea całożyciowego wychowania.

3. Wychowanie w poczuciu sprawiedliwości (sprawiedliwość w szkole).

4. Wychowanie ku wartościom pracy, przygotowanie do radzenia sobie w sytuacjach trudnych w życiu i na rynku pracy, wyuczona bezradność.

5. Wychowanie do odpowiedzialności.

6. Wychowanie do godności, wolności, odpowiedzialności, miłości, przyjaźni:

- godność, honor i duma (osobowa i narodowa),

- wychowanie patriotyczne i obywatelskie,

- wolność i jej karykatury,

- miłość i jej karykatury, wychowanie przez miłość do miłości,

- wychowanie ludzi dorosłych, wychowanie do starości (Bogaj, 2013).

IV. Zaniedbania w problematyce wychowania:

1. Wspomaganie w zakresie przygotowania do planowania życia osobowego, rodzinnego i zawodowego. 
2. Zaniedbania $\mathrm{w}$ przygotowaniu do życia $\mathrm{w}$ rodzinie $\mathrm{w}$ czasie popularyzacji idei LGBT („L” oznacza lesbijki, „G” - gejów, „B” - osoby biseksualne, a „T” - osoby transpłciowe) (Sierant, 2018).

3. Prognostyka pedagogiczna.

4. Zagubienie wychowania patriotycznego, w tym zagubienie kategorii obywatelskości.

5. Zagubienie problematyki tożsamości narodowej, tożsamości obywatelskiej.

6. Brak zapobiegania szerzącej się kulturze konsumenckiej (materializm praktyczny związany z dominacją myślenia kategoriami ekonomicznymi w miejsce kategorii etycznych).

7. Zaniedbania i zagubienie problematyki wykluczenia kulturowego i cywilizacyjnego, zapobieganie marginalizacji.

8. Nieobecność ochrony przed zagrożeniami cyberprzestępczości (Bogaj, 2013).

\section{ZAGUBIENIA W DYDAKTYCE}

Scjentystyczny paradygmat pedagogiki naukowej znalazł odbicie ze wszystkimi konsekwencjami w tradycyjnym modelu dydaktyki technologicznej leżącej u podstaw pozytywistycznej metodologii i behawiorystycznej psychologii, a także pedagogiki opartej o fenomenologiczną i personalistyczną koncepcję filozoficzną, hermeneutyczne założenia metodologiczne i poznawczą koncepcję psychologiczną. Powinna także zostać wykorzystana szansa, jaką daje nurt pedagogiki alternatywnej (Ratajek, 1996, s. 41):

1. Stereotypowość myślenia o problemach dydaktyki, w tym o samym procesie uczenia się człowieka.

2. Zagubienie problematyki dydaktyk szczegółowych.

3. Dydaktyka w biegu życia (dydaktyka form doskonalenia zawodowego).

4. Dydaktyka zawodowa.

5. Dydaktyka szkoły wyższej.

6. Inżynieria pedagogiczna (od problemów urbanistyki dotyczącej obiektów pedagogicznych do inteligentnych obiektów oświatowych).

\section{PRZEMIANY W TEORII UCZENIA SIĘ I NAUCZANIA}

Zagrożenia omówionego wyżej przeładowania informacyjnego owocują zagubieniem wartości poznawczej i edukacyjnej informacji. To zaś wymusza konieczność ponownego podjęcia badań nad teorią wiadomości edukacyjnych, co wiąże się z problematyką nowoczesnego kanonu wykształcenia ogólnego. Samo wyposażenie w wiedzę o proponowanej zmianie nie wystarczy, aby osiągnąć poziom efektywności danej zmiany. 
Konieczne w tej sytuacji jest wznowienie badań nad nowoczesną teorią uczenia się, w tym teorią samouctwa, teorią uczenia w nieklasycznych formach organizacji (np. e-learning).

Lokalizacja tych problemów wprowadza w kontekst europejskiej przestrzeni edukacyjnej konieczność prowadzenia badań nad europejskimi ramami kwalifikacji zawodowych, a dalej również nad kanonem wykształcenia ogólnego. Nie bez znaczenia jest wzmianka o konieczności badań nad psychopatologiami, jakie pojawiają się w procesach edukacyjnych w wyniku wszechobecności technologii informacyjnych. $\mathrm{Z}$ drugiej strony nowe kierunki badań nad sztuczną inteligencją i uczeniem się sieci w powiązaniu z osiągnięciami kognitywistki ukierunkowują naszą refleksję pedagogiczną na badania problematyki z zakresu neurodydaktyki.

Współczesna dydaktyka, przyjmując model pedagogiki humanistycznej, znacznie wzbogaciła się zarówno w swoich aspiracjach teoretycznych, jak i wobec zadań praktycznych. Znajduje się w niej bowiem miejsce nie tylko dla tradycyjnego modelu badawczego oraz indukcyjnego argumentowania i wnioskowania, lecz także dla nowego personalistycznego modelu widzenia osoby wychowanka, wspomaganego w rozwoju przez interpersonalne relacje na terenie szkoły i tworzone przez nauczyciela warunki. Takie pluralistyczne podejście zaowocowało znacznym rozszerzeniem terenu badań nauk pedagogicznych.

\section{ZAGUBIENIE EDUKACJI ZAWODOWEJ}

W wielu opracowaniach dąży się do uzasadnienia tezy, że w istocie chodzi o kompetencje miękkie i twarde (por. Furmanek, 2007). Wreszcie apeluje się o kompetencje, które są poszukiwane na rynku pracy. Wbudowuje się w ten sposób całą problematykę w relacje szkoła (edukacja, edukacja zawodowa) a rynek pracy. Warto w tym kontekście zainteresować się tymi tendencjami, przeanalizować je i ocenić z punktu widzenia współczesnej pedagogiki.

Bez wątpienia wyzwaniami podstawowymi, jakie stają przed edukacją zawodową, są te, które wynikają z przemian cywilizacyjnych i potrzeb człowieka podejmującego aktywność zawodową w zmieniających się warunkach, dlatego obecnie konieczne jest dostosowanie edukacji do potrzeb i oczekiwań społeczeństwa informacyjnego i gospodarki opartej na wiedzy ${ }^{1}$.

Wśród wielorakich wyzwań zwróćmy uwagę na konieczność włączenia do systemu pedagogicznego edukacji zawodowej oraz wymagań edukacji usta-

1 Pojęcie „społeczeństwo informacyjne” utożsamiane jest z pojęciem „społeczeństwo wiedzy”. Jak jednak słusznie zauważył Michał Goliński (2005, s. 14; por. Furmanek, 2004, s. 17-28), jest to dalej pojęcie mało ostre, o rozmytym znaczeniu, wykorzystywane i definiowane w różnych kontekstach dla różnych celów. 
wicznej. Chodzi m.in. o: kształtowanie postaw proedukacyjnych obywateli; upowszechnienie kształcenia ustawicznego związanego z nabywaniem i doskonaleniem kwalifikacji zawodowych (Kwiatkowski, 1996, s. 29-40) oraz kompetencji ogólnych (np. TIK, języki obce) (MENiS, 2003); zbudowanie przejrzystego systemu standardów kwalifikacji zawodowych (Kwiatkowski, Symela, 2001); zbudowanie systemu uznawania kwalifikacji zawodowych uzyskanych poza systemem poprzez certyfikację (uznanie formalne) oraz uznanie w praktyce (przez pracodawców) (Kwiatkowski, 1996); traktowanie w sposób priorytetowy ludzi starszych i o niskich kwalifikacjach (podtrzymanie aktywności zawodowej) oraz ludzi młodych, także po studiach wyższych (promowanie przedsiębiorczości i konkurencyjności) (Bogaj, 1997, s. 85-109).

\section{BIBLIOGRAFIA}

Bogaj, A. (1997). System edukacji w Polsce na tle porównawczym (próba analizy). W: A. Bogaj (red.), Realia i perspektywy reform oświatowych. Warszawa: Komitet Prognoz „Polska w XXI wieku" przy Prezydium PAN.

Bogaj, A. (2013). Zaniedbane obszary wychowania jako wyzwanie dla pedagogiki ogólnej (Referat na konferencji „Aksjologiczne orientacje w pedagogice”, 27 maja 2013). Pobrane z: https:// www.youtube.com/watch? v=_x9je_KPiCY (dostęp: 8.10.2018).

Furmanek, W. (2004). Ogólna charakterystyka przemian cywilizacyjnych. W: W. Furmanek, A. Piecuch (red.), Dydaktyka informatyki. Problemy teorii (s. 17-28). Rzeszów: Wydawnictwo URz.

Furmanek, W. (2007). Kompetencje kluczowe. Przegląd problematyki. W: W. Furmanek, M. Duris (red.), Kompetencje kluczowe. Studia porównawcze polsko-słowackie (s. 11-20). Rzeszów: Wydawnictwo URz.

Goliński, M. (2005). Społeczeństwo informacyjne - często (nie)zadawane pytania. E-mentor, 2(9). Gurycka, A. (1989). Struktura i dynamika procesu wychowania. Warszawa: PWN.

Hejnicka-Bezwińska, T. (red.). (1995). Pedagogika ogólna. Tradycja - teraźniejszość - nowe wyzwania. Bydgoszcz: Wydawnictwo Uczelniane WSP.

Kukołowicz, T. (1995). Pedagogika a teoria wychowania. W: T. Hejnicka-Bezwińska (red.), Pedagogika ogólna. Tradycja - teraźniejszość - nowe wyzwania (s. 71-75). Bydgoszcz: Wydawnictwo Uczelniane WSP.

Kwiatkowski, S.M. (1996). Cele i treści kształcenia w szkołach zasadniczych. W: E. Drogosz-Zabłocka (red.), Zmiany na rynku pracy a kształcenie zawodowe (s. 29-40). Warszawa: PWN.

Kwiatkowski, S.M., Symela, K. (2001). Standardy kwalifikacji zawodowych. Teoria, metodologia, praktyka. Warszawa: IBE.

MENiS. (2003). Strategia rozwoju kształcenia ustawicznego do roku 2010 (dokument przyjęty 8 lipca 2003 roku przez Radę Ministrów). Edukacja Ustawiczna Dorostych, (3), 7-28.

Nowak, M. (2009). Modele uprawiania filozofii wychowania. W: A. Szudra, K. Uzar (red.), Personalistyczny wymiar filozofii wychowania (s. 77-97). Lublin: Wydawnictwo KUL.

Palka, S. (red.). (1998). Orientacje w metodologii badań pedagogicznych. Kraków: Wydawnictwo UJ. 
Palka, S. (2009). Filozofia wychowania i filozofia w wychowaniu - szkic metodologiczny. W: A. Szudra, K. Uzar (red.), Personalistyczny wymiar filozofii wychowania (s. 99-107). Lublin: Wydawnictwo KUL.

Palka, S. (2010). Metodologia, badania, praktyka pedagogiczna. Gdańsk: GWP.

Ratajek, Z. (1996). Dydaktyka wobec problemów współczesnej pedagogiki. Zeszyty Wszechnicy Świętokrzyskiej, (3), 35-49.

Sierant, A. (2018). LGBT: co oznacza ten skrót? Środowisko LGBTw Polsce. Pobrane z: https://www. poradnikzdrowie.pl/psychologia/rozwoj-osobisty/lgbt-co-oznacza-ten-skrot-srodowisko-lgbtw-polsce-aa-twdU-BWjU-SXyz.html (dostęp: 4.04.2018).

Śliwerski, B. (2015). Gra w dyskurs krytyczny. Pobrane z: http://sliwerski-pedagog.blogospot.com2015/01 gra-w-dyskurs-krytyczny.html (dostęp: 4.04.2018).

\section{SUMMARY}

This study presents catalogs of problems combining on the lost areas of Polish pedagogy. Attention was drawn to the need to clearly define the mission of pedagogical sciences. It cannot ignore the answer to the question about the essence of man (problems of anthropology and axiology). These, in turn, refer to the philosophical foundations of modern pedagogy. The adopted human image indicates the attributes of the subject: human as a person (complementing the naturalistic paradigm with the humanist paradigm). With regard to these human attributes, pedagogical activity is related. Its essence is to support development processes. No less important is everything related to the so-called fields of education. There is a need to abandon the additivity that is widespread in this area. How should these issues be perceived in the light of the requirements of the methodology of systemic research and the challenges of the modern civilization of knowledge? All this is reflected in the lost problem of pedagogical axiology and education in light and towards values. The issue of human learning - in the context of ubiquitous information technologies - also requires a new approach, and this reorganizing the problem of detailed didactics, including vocational education.

Keywords: anthropology; upbringing; negligence; loss; theory of education; teaching theory 